\title{
O PEnSAMEnto de MarX \\ SOBRE A SUBJETIVIDADE
}

\author{
Eduardo F. Chagas ${ }^{l}$
}

RESUMO: O pensamento de Karl Marx sobre a subjetividade humana é pouco conhecido e divulgado na língua portuguesa, e, no Brasil, particularmente, carece ainda de um estudo amplo, explícito e sistemático. Meu artigo pretende esboçar uma reflexão mais completa de sua filosofia sobre a subjetividade humana, insistindo não somente na crítica, mas também, e especialmente, na compreensão da referida questão, a partir de uma leitura imanente e estrutural de suas obras, no original. Vale ainda ressaltar que minha investigação se apoia na conexão entre subjetividade e objetividade, entre sujeito e objeto, inquirindo se há um determinismo da objetividade sobre a subjetividade, ou seja, se essas duas determinaçōes são contraditórias no interior do pensamento marxiano, comprometendo, pois, as suas reflexóes acerca da crítica à filosofia especulativa de Hegel e ao empirismo da economia clássica, ou se, na verdade, tal conexáo é o segredo recôndito de sua filosofia sobre a subjetividade humana.

PALAVRAS-CHAVE: Marx. Subjetividade. Determinismo.

A questão da subjetividade no pensamento de Marx permanece, ainda hoje, amplamente inexplorada, sendo, inclusive, tratada, por determinadas correntes no interior do pensamento marxista, de forma preconceituosa, como uma questão secundária a ser desconsiderada. ${ }^{2}$ Alguns autores apontaram-na como uma deficiência, tendo em vista que, para estes, há na obra de Marx um forte traço economicista e determinista, à medida que ele compreende os mecanismos internos, as atividades da consciência, como um fenômeno secundário, mero reflexo das determinaçóes materiais, das relações de produção, inviabilizando, assim, uma reflexão rica e complexa sobre a subjetividade humana. Tais posiçóes se baseiam, de forma apressada,

\footnotetext{
${ }^{1}$ Doutor em Filosofia; professor da Graduação e da Pós-Graduação do Curso de Filosofia da Universidade Federal do Ceará (UFCE) e colaborador do Programa de Pós-Graduação da Faculdade de Educaçấo (FACED) da UFC. E-mail: ef.chagas@uol.com.br.

${ }^{2}$ Cf. SILVEIRA, Maria Lídia Souza da. Algumas notas sobre a temática da subjetividade no âmbito do marxismo. Revista Outubro, No. 7, p. 103, 2002.
} 
em algumas passagens na obra de Marx, particularmente em $A$ Ideologia Alemã (Die deutsche Ideologie) (1845-1846), na qual ele afirma que é a vida que determina a consciência, e não o contrário, e no Prefácio (Vorwort) à obra Para a Critica da Economia Política (Contribuição) (Zur Kritik der politischen Ökonomie) (1859), em que ele reafirma tal posição, salientando que "[...] não é a consciência dos homens que determina o seu ser, mas, ao contrário, é o seu ser social que determina a sua consciência."” Ser um ser social quer dizer aqui não mais vida em geral, abstrata, mas uma qualidade de vida, a vida determinada, a vida social humana. E o ser social, que determina a consciência, está, por sua vez, condicionado historicamente pela produção material da vida, produção essa que significa não só produção econômica (economicismo), mas produção e reprodução dos meios necessários à vida, à sobrevivência humana, que envolve tanto produção de bens materiais quanto de bens imateriais, produção de objetividade e subjetividade, de elementos objetivos e subjetivos. Todavia, isso foi interpretado por aquelas "posiçóes críticas" como uma debilidade no pensamento de Marx, levando a um reducionismo econômico, a um rude objetivismo, a um mecanicismo entre a esfera da produção da existência (determinante) e a esfera da subjetividade, das ideias e da consciência (determinada), sem uma ideia de unidade ou de práxis como mediação entre a objetividade e a subjetividade, entre o material (o econômico) e o espiritual, entre a base e a superestrutura. $\mathrm{Na}$ verdade, essa crítica feita a Marx é, ao meu ver, insatisfatória, pois ela se baseia em um suposto objetivismo marxiano ou em "imagens arquitetônicas", "conceitos metafóricos", infraestrutura (base) e superestrutura, tomados, mecanicamente, a partir de um fator determinante diante dos demais, ou seja, de uma suposta prevalência da base econômica da sociedade sobre a superestrutura ideológica, que levaria ao predomínio do sujeito econômico em detrimento do indivíduo como sujeito histórico e, com isso, até à negação do próprio sujeito, ao sumiço do espaço da subjetividade humana. Mas esses conceitos base econômica e superestrutura ideológica são arbitrários, falhos e imprecisos para explicar a especificidade dos momentos da objetividade e da subjetividade como partes de um todo. Essas imprecisóes náo podem ser atribuídas a Marx, tendo em vista que ele não considera a produção material e a produção espiritual como dois momentos cristalizados, estáticos, mas sim como dois instantes que se operam ao mesmo tempo, como partes integrantes da totalidade social. Marx deixa claro isso, ao frisar, nas Teorias

${ }^{3}$ MARX, K. Vorwort zur Kritik der politischen Ökonomie. In: MARX, K.; ENGELS, F. Werke (MEGA). Berlin: Dietz, 1983, v. 13, p. 9. 
da Mais-Valia (Theorien über den Mehrwert), que há uma conexão entre a produção intelectual e a material e que esta última não deve ser considerada "[...] como categoria geral, mas em forma histórica determinada. [...] Se não se concebe a própria produção material em sua forma histórica específica, é, então, impossível compreender o que é determinado em sua produção espiritual correspondente e a ação recíproca entre ambas." ${ }^{4}$ Portanto, não há em Marx uma supervalorização do aspecto socioeconômico em relação à dimensão da "superestrutura", ou seja, para Marx, não se trata de uma valorização, em que uma é mais importante do que a outra, ou em que uma é determinante e ativa e a outra determinada e passiva, mas de uma recíproca influência de uma sobre a outra. ${ }^{5}$

Marx náo compreende a subjetividade como um simples reflexo das determinaçóes da base econômica, como um mero produto do econômico, e sim como um componente inseparável dos processos de formação da vida humana. $\mathrm{O}$ seu pensamento não pode ser reduzido a um objetivismo, a um mero determinismo econômico, unilateral, visto que a objetividade é impensável sem uma íntima correspondência com a subjetividade. Não há, para ele, objeto sem sujeito, como não há sujeito sem objeto. Nenhum dos polos dessa relação, sujeito e objeto, é posto como um dado a priori; eles se constituem na relação. Quer dizer, Marx não considera o indivíduo humano apenas no seu caráter objetivo, determinado, mas em seu processo de autodeterminação. E é nesse processo de autoconstrução que se criam novas formas de objetivação, que possibilitam, por sua vez, novas formas de subjetivação. ${ }^{6} \mathrm{O}$ que Marx quer mostrar é, na verdade, que a subjetividade não é nem uma instância própria, autônoma, independente, abstrata, nem posta naturalmente, dada imediatamente ao indivíduo, mas construída socialmente, produzida numa dada formação social, num determinado tempo histórico. Em consequência, a sua reflexão sobre a subjetividade não pode deixar de lado, por exemplo, uma análise da sociedade capitalista que a forja.

\footnotetext{
${ }^{4}$ MARX, K. Theorien über den Mehrwert. In: MARX, K.; ENGELS, F. Werke (MEGA). Berlin: Dietz, 1965, v. 26.1, p. 257.

${ }^{5}$ Cf. BERINO, Aristóteles P. Elementos para uma teoria da subjetividade em Marx. Dissertaçāo (Mestrado) - Niterói/RJ, 1994 (mimeo). Cf. também ARAÚJO, Ronaldo Marcos de Lima; TEODORO, Elinilze Guedes. Aproximaçôes para entender a subjetividade numa perspectiva marxista. Revista Trabalho e Educação: NETE/UFMG. v. 15, n.1, 2006.

${ }^{6}$ Cf. SILVEIRA, Paulo; DORAY, Bernard. Elementos para uma teoria marxista da subjetividade. São Paulo: Vértice, 1989. Cf. também BERINO, Aristóteles P. op. cit., p. 11.
} 
Não há, todavia, uma obra específica de Marx acerca da subjetividade, ou uma obra em que ele tenha tratado diretamente dela, mas, no conjunto de seus escritos, desde suas primeiras reflexōes até as formulaçôes mais amadurecidas, há passagens, elementos básicos, constitutivos, para uma construção teórica da subjetividade em Marx. Contra os que acham não ser possível apontar uma teoria da subjetividade em Marx, penso que ele refletiu, sim, em diversos momentos, sobre a subjetividade humana, momentos esses que podem ser evidenciados, entre outras, nas seguintes obras: Contribuição à Crítica da Filosofia do Direito de Hegel - Introdução (Zur Kritik der hegelschen Rechtsphilosophie. Einleitung) (1844), A QuestãoJudaica (ZurJudenfrage) (1844), Manuscritos Econômico-Filosóficos (Ökonomisch-philosophische Manuskripte) (1844), Teses sobre Feuerbach (Thesen über Feuerbach) (1845-1846), A Ideologia Alemã (Die deutsche Ideologie) (1845-1846), O 18 Brumário de Luís Bonaparte (Der achtzehnte Brumaire des Louis Bonaparte) (1852), os Fundamentos (Grundrisse) (1857-1858), Para a Critica da Economia Politica (Zur Kritik der politischen Ökonomie) (Prefácio) (1859) e O Capital (Das Kapital) (1867). Ao longo de sua obra, Marx desenvolve elementos constitutivos para se entender a subjetividade humana, como: 1. a subjetividade não como autônoma, abstrata; 2. a subjetividade não como dada naturalmente, imediatamente ao indivíduo; 3. a subjetividade como construída historicamente; e 4. a importância da presença da subjetividade na construção, na transformação, na apreensão e na interpretaçáo cognitiva do real, da realidade. E, para compreender a subjetividade no âmbito da sociedade capitalista, Marx nos dá, entre outros, diversos conceitos, como: ilusão, trabalho, estranhamento, "base" e "superestrutura", ideologia, ocultação, inversão e fetichismo da mercadoria.

Nos primeiros textos de Marx, é muito importante os conceitos de ilusão, fragmentação e cisão, que eram também centrais no pensamento de Ludwig Feuerbach. Para este, o homem é, na sociedade moderna, um ser fragmentado, separado de sua essência, e é, precisamente, essa separação que se explica o processo subjetivo da fé, da crença religiosa. Esta Feuerbach vê como um produto da subjetividade humana marcada pela cisão entre sua essência, o gênero, o universal, e sua existência singular, individual. Como o homem não pode efetivar, na sua existência singular, o gênero, o universal, ele o projeta para fora de si, num ser exterior a ele (= em Deus). Resulta daqui que o objeto (o homem) se torna sujeito, e o sujeito (o gênero, Deus) torna-se objeto, pois não foi Deus que criou o homem, mas o homem quem criou subjetivamente Deus à sua imagem e semelhança. Mas, na religião, essa verdade antropológica não é evidente, já que o que aparece é uma inversão: Deus como sujeito 
(como criador), e o homem como predicado (como criatura). A pretensão de Feuerbach é inverter essa inversão e mostrar que a discórdia, a oposição, entre Deus (o divino, o sagrado) e o homem (o humano, o profano) é ilusória, porque o conteúdo da religião é inteiramente humano. Portanto, o homem só tomará consciência que Deus é uma projeção de sua subjetividade, de sua própria essência subjetiva, tomada de forma absoluta, quando converter a teologia em antropologia. ${ }^{7}$

Embora também, para Marx, o homem, na modernidade, se encontre isolado, separado de sua essência, esta não é, para ele, uma essência subjetiva, tal como o é para Feuerbach. Isto Marx deixa claro na Contribuição à Crítica da Filosofia do Direito de Hegel - Introdução, quando ele afirma que a essência do homem é "o mundo do homem", a sua sociedade. E, nas $6^{\mathrm{a}}$ e $8^{\mathrm{a}}$ Teses sobre Feuerbach, enfatiza ele que a essência humana não é uma abstração inerente ao indivíduo, como uma generalidade interna, muda, nem é dada naturalmente, mas sim uma construção do próprio homem, a partir do conjunto das relações sociais. Nesse sentido, Marx não se limitará, como o fez Feuerbach, a criticar a religião como necessidade subjetiva da ilusão, desconsiderando a base material que a produz, ou seja, a miséria do mundo real "[...] que necessita de ilusóes." Marx pretende aqui estabelecer uma relação indissociável entre a base real (a sociedade) e as criaçóes subjetivas resultantes dessa base, por isso, para ele, o enfrentamento das ilusôes subjetivas não pode dar-se por intermédio de soluções imaginárias ou fantásticas, postulando uma felicidade ilusória num mundo melhor, numa outra vida, porque, enquanto a raiz social (a sociedade) da fragmentação, da mutilação humana, não for superada, a dor, o sofrimento subjetivo não pode ser aliviado, sossegado.

Numa outra obra ainda de juventude, A Questão Judaica, Marx polemiza com Bruno Bauer, para quem a base da fragmentação humana e das ilusôes religiosas seria o Antigo Regime (o Estado religioso), no qual o homem se encontra mutilado entre a sua vida singular e o seu ser genérico, universal. Para Bauer, a solução para a fragmentação humana e para as ilusóes subjetivas seria a política democrático-burguesa, a qual, ao garantir a cidadania e a

${ }^{7}$ Cf. BERTRAND, Michele. O homem clivado - A crença e o imaginário. In: SILVEIRA, P.; DORAY, B. Elementos para uma teoria marxista da subjetividade. Op. cit., p. 16. Ver também CHAGAS, Eduardo F. Religião: O homem como imagem de Deus ou Deus como imagem do homem. In: CHAGAS, E. Formação Humana: Liberdade e Historicidade. Fortaleza: Ediçôes UFC, 2004, p. 86-105 (Coleção Diálogos Intempestivos, v. 16).

${ }^{8}$ MARX, K. Zur Kritik der hegelschen Rechtsphilosophie. Einleitung. In: MARX, K.; ENGELS, F. Werke (MEGA). Berlin: Dietz, 1957, v. 1, p. 379. 
liberdade, reintegraria o universal à singularidade de cada indivíduo numa particularidade histórica. Marx mostra, contra Bauer, que o Estado moderno, longe de suprimir, eleva ao máximo a fragmentação humana, como também aparece como religioso, embora ele seja profano e laico. No Estado moderno, a universalidade, a generalidade, localiza-se na cidadania, nos direitos humanos, mas não permite ao sujeito fragmentado reencontrar a sua unidade, pois a universalidade presente nele não é concreta, efetiva, mas abstrata, formal. No Estado moderno, o sujeito é reconhecido como cidadáo, como um ser universal, mas essa idealidade universal está separada, abstraída, de sua existência real e particular. Ressalta Marx:

Onde o Estado político alcançou seu verdadeiro desenvolvimento, o homem leva, não só no pensamento, na consciência, mas na realidade, na vida, uma dupla vida - celeste e terrestre - a vida na comunidade política, em que ele vale como ser comunitário, e a vida na sociedade burguesa, em que ele é ativo como homem privado. ${ }^{9}$

No Estado [...], onde o homem vale como ser genérico, ele é o membro imaginário de uma soberania quimérica, está despojado de sua real existência individual e repleto de uma universalidade irreal. ${ }^{10}$

O Estado moderno faz abstração do homem real e só o satisfaz de forma imaginária, abstrata. Tal Estado não pode, pois, suprimir as raízes da fragmentação e da ilusão humana; ele é, antes, a fonte da religiosidade, à medida que ele aparece, agora, como uma comunidade ilusória, como um universal abstrato, tal como o Deus cristáo, como um ser ilimitado, todo poderoso, sem o qual o sujeito não pode subsistir.

Como objeção a uma possível teoria da subjetividade em Marx, muitos autores destacam ainda a seguinte passagem de Para a Crítica da Economia Política:

O resultado geral a que cheguei e que, uma vez obtido, serviu-me de fio condutor nos meus estudos, pode ser formulado resumidamente assim: na produção social da sua vida, os homens contraem relaçóes determinadas, necessárias e independentes de sua vontade, relações de produção que correspondem a um determinado grau de desenvolvimento das suas forças produtivas materiais. A totalidade

\footnotetext{
${ }^{9}$ MARX, K. Zur Judenfrage. In: MARX, K.; ENGEL, F. Werke (MEGA). Berlin: Dietz, 1957, v. 1. p. 354-355.

${ }^{10}$ Ibid., p. 355. Sobre a crítica de Marx à política liberal-burguesa e ao Estado moderno, cf. também CHAGAS, Eduardo F. A crítica da política em Marx. In: CHAGAS, E. Trabalho, Filosofia e Educação no Espectro da Modernidade Tardia. Fortaleza: Ediçōes UFC, 2007, p. 67-82.
} 
destas relaçóes de produção forma a estrutura econômica da sociedade, a base real sobre a qual se eleva uma superestrutura jurídica e política, e à qual correspondem formas de consciência determinadas socialmente. $\mathrm{O}$ modo de produçáo da vida material condiciona em geral o processo de vida social, político e espiritual. [...] Com a transformação da base econômica, toda a enorme superestrutura se transforma com maior ou menor rapidez. Na consideração de tais transformaçóes é necessário distinguir sempre entre a transformação material, que se pode constatar fielmente na ciência natural, das condições econômicas de produção e as formas jurídicas, políticas, religiosas, artísticas ou filosóficas, em resumo, as formas ideológicas pelas quais os homens tomam consciência deste conflito e o conduzem até o fim. Assim como não se julga um indivíduo pela ideia que ele faz de si próprio, náo se pode julgar tão pouco uma época tal de transformaçáo pela sua consciência, mas, pelo contraio, deve-se explicar a esta consciência pelas contradiçóes da vida material, pelo conflito que existe entre as forças sociais produtivas e as relaçóes de produção. ${ }^{11}$

É preciso esclarecer que as referências de Marx, nessa passagem, aos conceitos de "base econômica" e "superestrutura" apontam para questóes de método, e não para uma suposta supremacia mecânica da vida material sobre a vida espiritual. Sua intenção é demarcar seu método ${ }^{12}$ como distinto do método empirista da economia política, que parte, sim, da objetividade, do real, mas permanece no seu nível simples, aparente, empírico-imediato, sem, contudo, cair, por outro lado, no método especulativo-hegeliano, que concebe a objetividade, o real, apenas como um resultado da subjetividade, da atividade do conceber, como um produto do pensamento, fechado e concentrado em si mesmo. E, embora faça valer a prioridade ontológica da objetividade, do real ante ao real construído só idealmente, abstratamente no pensamento, Marx náo nega, de maneira nenhuma, o momento em que o real, a partir do próprio real, deva ser reconstruído pela subjetividade (pelo pensamento) como concreto pensado. Portanto, ao afirmar que o ser social determina a subjetividade (a consciência), Marx não quis dizer que a subjetividade (a consciência) é uma atividade secundária, já que, para ele, é, precisamente, com base na consciência das circunstâncias em que a vida é produzida que o sujeito reconstrói, transforma e apreende o mundo, e adquire para si a sua liberdade.

\footnotetext{
${ }^{11}$ MARX, K. Vorwort zur Kritik der politischen Ökonomie. op. cit., p. 8-9.

${ }^{12}$ Sobre o método de Marx, cf. CHAGAS, Eduardo F. O Método Dialético de Marx: investigação e exposição crítica do objeto. Síntese - Revista de Filosofia. Belo Horizonte, v. 38, n. 120, p. 55-70, 2011.
} 
Também em $O 18$ Brumário de Luis Bonaparte (1852), veem-se referências de Marx à relação entre a base econômica e a superestrutura. Sobre isso, escreve ele o seguinte:

Sobre as diferentes formas de propriedade, sobre as condiçôes sociais de existência ergue-se toda uma superestrutura de sensaçóes, ilusóes, modos de pensar e visóes de vida distintas e peculiarmente formadas. A classe inteira cria-os e forma-os a partir das suas bases materiais e das relaçôes sociais correspondentes ${ }^{13}$.

Marx designa aqui como superestrutura os preconceitos, as ilusóes, as convicções, os princípios, ou seja, a visão de mundo de uma classe social, o seu modo de pensar, criado por suas condiçóes materiais de vida. A superestrutura não pode, nesse sentido, ser compreendida, tal como no Prefácio à obra Para a Crítica da Economia Política, como um mero reflexo da base econômica, visto que ela constitui um campo complexo em que se formam os símbolos, os valores, os sentimentos, as ideias, as imagens, as representaçóes, nas quais uma dada sociedade é reconhecida. E é através dessas representaçóes, no âmbito "superestrutural", que os indivíduos assumem seus interesses, expressam a maneira de enxergar a sua existência na sociedade, a consciência que eles têm das condiçóes reais da sua existência, não ocultando, pois, os seus interesses, as suas reais motivaçóes.

O que os [os lojistas] fazem representantes da pequena-burguesia é que eles náo ultrapassam na cabeça os limites dos quais esta não ultrapassa na vida; que eles, portanto, são teoricamente impulsionados para as mesmas tarefas e soluçōes, para as quais o interesse material e a posição social impulsionam, na prática, aquela [a pequena-burguesia]. ${ }^{14}$

Os burgueses e pequenos burgueses defendem ideias que não ultrapassam o mundo do capital e, quando almejam transformaçóes, estas se dão via democracia liberal-burguesa, dentro dos limites das instituiçóes sociais existentes.

O problema é que o sujeito trabalhador, que faz parte do mundo do trabalho, tem uma representação de sua existência, uma compreensão de sua

\footnotetext{
${ }^{13}$ MARX, K. Der achtzehnte Brumaire des Louis Bonaparte. In: MARX, K.; ENGELS, F. Werke (MEGA). Berlin: Dietz, 1960, v. 8, p. 139.

${ }^{14}$ Ibid., p. 142.
} 
vida, a qual não corresponde à sua real circunstância, justamente porque tal representaçáo náo expressa a sua existência e o seu mundo, mas a existência e o mundo do burguês, a "visão de mundo" do capital. Dessa maneira, destaca Marx: "E assim como na vida privada se distingue entre o que um homem pensa e diz de si próprio e o que ele realmente é e faz, assim nas lutas históricas deve-se distinguir mais ainda as frases e as imaginaçôes dos partidos de seu organismo efetivo e de seus interesses efetivos, sua representação de sua realidade". ${ }^{15} \mathrm{Ou}$, ainda:

A tradição de todas as geraçóes mortas pesa como um pesadelo sobre o cérebro dos vivos. E, precisamente, quando estes parecem ocupados em revolucionar a si e as coisas, em criar algo que ainda não existe, é precisamente nestas épocas de crise revolucionária que eles evocam temerosamente em seu favor os espíritos do passado, pedem emprestados os seus nomes, as suas palavras de guerra, a sua roupagem, para, neste venerável disfarce tradicional e com esta linguagem emprestada, representar a nova cena na história universal. ${ }^{16}$

\section{Em contrapartida,}

[a] revolução social do século XIX não pode tirar a sua poesia do passado, mas apenas do futuro. Náo pode começar consigo mesma antes de se desfazer de todas as superstiçôes do passado. As revoluçóes anteriores precisaram das reminiscências da história universal, para se anestesiarem de seu próprio conteúdo. A revolução do século XIX tem que deixar os mortos enterrarem os seus mortos, para chegar ao seu próprio conteúdo. Lá, a frase ultrapassava o conteúdo; aqui o conteúdo ultrapassa a frase. ${ }^{17}$

Longe de negar a subjetividade, Marx dá-lhe importância central no processo de transformaçăo ${ }^{18}$, pois ele reconhece também a influência que

\footnotetext{
${ }^{15}$ Ibid., p. 139.

${ }^{16}$ Ibid., p. 115.

${ }^{17}$ Ibid., p. 117.

${ }^{18}$ A crítica de Marx ao materialismo de Feuerbach, em 1845-46, é, entre outras questôes, porque este deixou de lado a atividade subjetiva humana. Na primeira Tese ad Feuerbach, afirma Marx: "A insuficiência principal de todo materialismo até os nossos dias (o de Feuerbach inclusive) é que o objeto, a realidade, a sensibilidade foi tomado apenas sob a forma de objeto ou de intuição; mas náo como atividade humana sensível, como práxis, não subjetivamente." Cf. MARX, $\mathrm{K}$. Thesen über Feuerbach. In: MARX, K.; ENGELS, F. Werke (MEGA). Berlin: Dietz, 1958, v. 3, p. 533. E, em A Ideologia Alemá, Marx evidencia, de forma mais articulada, que Feuerbach tem o mundo como algo já constituído, estático, imutável, a-histórico, desconhecendo as modificaçōes que a subjetividade
} 
a cultura, os "movimentos culturais", as tradições das geraçóes "mortas", passadas, exerce sobre as geraçóes vivas, do presente. Dessa forma, para haver emancipação, revolução social, é necessária não só uma transformação das condiçôes materiais, mas também da subjetividade humana, que, para agir crítico e emancipadamente sobre o mundo, terá que renunciar às referências, às imagens do passado que não ultrapassam a ordem social do capital.

No que se refere à subjetividade em Marx, com base em uma suposta determinação da base econômica sobre a superestrutura ideal, é importante citar ainda A Ideologia Alemã (1845-1846). Nessa obra, inicialmente, Marx e Engels criticam os neo-hegelianos, principalmente Bruno Bauer, Max Stirner e Ludwig Feuerbach, pelo fato de admitirem a autonomização da consciência e de defenderem a modificação do mundo a partir tão-somente da negação subjetiva das ilusôes da consciência. Assim se expressam Marx e Engels:

Os ideólogos jovens hegelianos são, apesar de suas frases que pretensamente "abalam o mundo", os maiores conservadores. Os mais jovens dentre eles encontraram a expressão correta para a sua atividade, quando afirmam que lutam apenas contra "frases". Eles esquecem, apenas, que opóem a estas frases nada mais do que frases, e que eles, quando combatem apenas as frases deste mundo, não combatem, de forma alguma, o mundo real existente. ${ }^{19}$

Para Marx e Engels, ao contrário, o ponto de partida para a transformação efetiva do mundo não está na atividade isolada da consciência, mas nas condiçóes materiais dos indivíduos, condiçóes estas dadas pelo trabalho, pela produção de seus meios de vida. E são nessas condiçóes materiais, reais, de produção da existência que os indivíduos formam a sua consciência, a sua visão de mundo. Como eles afirmam:

implementou nele: Feuerbach "[...] não vê que o mundo sensível que o rodeia não é uma coisa dada imediatamente da eternidade, uma coisa sempre igual a si mesma, mas antes o produto da indústria e do estado em que se encontra a sociedade, e, na verdade, no sentido de que ele é um produto histórico, o resultado da atividade de toda a uma séria de geraçóes”. Mais adiante, enfatiza Marx "[...] que Feuerbach, em Manchester, por exemplo, vê apenas fábricas e máquinas, onde há cem anos atrás havia apenas rodas de fiar e teares manuais". Cf. MARX, K. Die deutsche Ideologie. In: MARX, K.; ENGELS, F. Werke (MEGA). Berlin: Dietz, 1958, v. 3, p. 43-44. Cf. também MARTINS, Maurício Vieira. Materialismo e Subjetividade: estudando a posiçấo de Marx. In: MORAES, João Quartim de (Org.). Materialismo e Evolucionismo - Epistemologia e História dos Conceitos. Campinas: FAPESP, 2007, p. 103-130. (Coleção CLE, v. 47).

${ }^{19}$ MARX, K.; ENGELS, F. Die deutsche Ideologie. op. cit., p. 20. 
Os homens são os produtores de suas representaçóes, de suas ideias etc., mas os homens reais, ativos, como eles são condicionados por um desenvolvimento determinado de suas forças produtivas e pelo intercâmbio que a eles corresponde até chegar às suas formaçóes mais amplas. A consciência nunca pode ser outra coisa senão o ser consciente, e o ser dos homens é o seu processo real de vida. Se em toda ideologia os homens e suas relaçóes aparecem de cabeça para baixo como numa câmara obscura, é porque este fenômeno deriva do seu processo histórico de vida, da mesma maneira que a inversão dos objetos na retina deriva imediatamente do seu processo físico de vida. ${ }^{20}$

Marx e Engels designam aqui como ideologia a consciência invertida, a consciência fracionada do mundo, tal como a inversáo das imagens na câmara escura, isto é, a totalidade das formas de consciência social a qual inverte a relação entre ela e as contraditórias condiçôes de produção da existência, tomando a si mesma como condição geradora do mundo, e náo o contrário, ou seja, uma inversão da relação entre a consciência e a realidade concreta, entre o pensar e o ser, tomando a consciência e as suas ideias como autônomas, e tendo supremacia sobre a realidade. Mas, como eles sublinham:

Não é a consciência que determina a vida, é a vida que determina a consciência. No primeiro modo de consideraçáo, parte-se da consciência como indivíduo vivo; no segundo, que corresponde à vida real, parte-se dos próprios indivíduos vivos reais e considera-se a consciência apenas como a sua consciência. ${ }^{21}$

A ideologia como inversão leva a uma "falsa consciência", mas uma "falsa consciência" náo como mero erro subjetivo, como falsidade das ideias, descolada da realidade, abstraída da materialidade, porém, como distorção específica de uma realidade específica e, no caso de Marx, como visão distorcida da realidade capitalista, na medida em que esta aparece como uma realidade a-histórica, não produzida, sem contradição, sem conflitos e válida universalmente.

Embora as formas de ideologias - que se expressam através das instituiçôes criadas pelo homem para a sua organização social, como as formas jurídicas, políticas, religiosas, artísticas ou filosóficas - sejam formas de

\footnotetext{
${ }^{20}$ Ibid., p. 26.

${ }^{21}$ Ibid., p. 27.
} 
consciência apartadas do mundo, que deixam de corresponder à base material de sua existência, de sua própria criação, ou seja, esferas superestruturais que não permitem ao indivíduo uma consciência crítica, coerente, acerca das condiçôes sociais existentes, nem das contradiçóes da realidade, conservando e reproduzindo, assim, a ordem social estabelecida, as ideologias não podem ser compreendidas, como comumente se atribui erroneamente a Marx, simplesmente como "falsas consciências", o que levaria a entendê-las, tal como a subjetividade, de forma reduzida, pobre, como meras "realidades ilusórias", como produçóes autônomas da consciência. pois elas têm, na verdade, seu fundamento não em si mesmas, na consciência apartada do mundo, mas na base material da sociedade. Por isso, Marx e Engels enfatizam que a visão de mundo predominante, as ideias dominantes, são as ideias produzidas pela classe hegemônica e expressam, sim, as condiçóes materiais, através das quais essa classe realiza seu domínio. Assim, expressam-se eles:

As ideias da classe dominante são, em cada época, as ideias dominantes, isto é, a classe, que é o poder material dominante da sociedade, é, ao mesmo tempo, seu poder espiritual dominante. A classe, que tem à sua disposição os meios para a produçáo material, dispôe assim, ao mesmo tempo, dos meios para a produção espiritual, de modo que a ela estấo, assim, ao mesmo tempo, submetidas em média as ideias daqueles a quem faltam os meios para a produção espiritual. As ideias dominantes não são mais do que a expressão ideal das relaçôes materiais dominantes, as relações materiais dominantes concebidas como ideias; portanto, das relaçôes que precisamente tornam uma classe dominante, portanto, as ideias de seu domínio. Os indivíduos, que constituem a classe dominante, têm, entre outras coisas, também consciência, e, por conseguinte, pensam; à medida que eles dominam como classe e determinam todo o âmbito de uma época histórica, é evidente que o fazem em toda a sua extensão, e, portanto, entre outras coisas, dominam também como pensadores, como produtores, de ideias; que regulam a produçáo e a distribuiçáo das ideias do seu tempo, que, portanto, as suas ideias são as ideias dominantes da época. ${ }^{22}$

Essas ideias hegemônicas, propostas pelas classes dirigentes, são apresentadas para toda a sociedade como um ideal comum, pertencente a todos.

Dando sequência às bases de uma teoria da subjetividade no pensamento de Marx, é importante citar aqui também Os Manuscritos

${ }^{22}$ MARX, K/ENGELS, F. Die deutsche Ideologie. op. cit., p. 46. 
Econômico-Filosóficos (1844), nos quais se pode perceber a influência do trabalho na constituição da subjetividade humana. Nessa obra, Marx, ao tratar da categoria trabalho, toma-a, inicialmente, como uma categoria fundante da produção e reprodução da vida humana - a atividade primária, necessária e natural do homem. Precisamente, o que especifica a essência de um ser vivo é a forma como vive, produz e reproduz sua vida. Marx afirma: "No modo da atividade vital encontra-se o caráter inteiro da espécie, seu caráter genérico, e a atividade consciente livre é o caráter genérico do homem." ${ }^{23} \mathrm{~A}$ atividade dos demais animais se reduz exclusivamente ao consumo dos objetos de suas próprias necessidades imediatas. Essa forma de atividade, mesmo a mais deslumbrante, é repetição instintiva e quase mecânica, e, por isso, norteada apenas a uma necessidade específica, restrita e impulsionada de acordo com a própria estrutura orgânica. Frisa Marx:

$\mathrm{Na}$ verdade, o animal também produz. Constrói para si um ninho, habitações, como a abelha, o castor, a formiga etc. Mas só produz o que necessita imediatamente para si ou para sua cria; produz unilateralmente [...]; o animal produz apenas sob o domínio da necessidade física imediata [...]; ele produz apenas para si mesmo [...]. O animal forma apenas segundo a medida e a necessidade da espécie a que pertence. ${ }^{24}$

Tais operaçôes deslumbrantes, segundo Marx, não constituem trabalho, pois são realizadas sem pressupor um momento subjetivo, sem um fim subjetivo, sem uma teleologia, sem uma idealidade, tal como acontece com o trabalho humano. $\mathrm{O}$ trabalho não é um simples fazer fortuito, mecânico e restrito, mas uma atividade voltada para um fim, que é uma determinação da subjetividade humana, uma atividade livre e consciente, subordinada à vontade, uma vez que o sujeito, antes de fazer, constrói subjetivamente sua obra, imprimindo nela o projeto que tinha a priori na sua subjetividade ${ }^{25}$. Através do trabalho, o sujeito manifesta-se como ser genérico, suplanta a

\footnotetext{
${ }^{23}$ MARX, K. Ökonomisch-philosophische Manuskripte. In: MARX, K.; ENGELS, F. Werke (MEGA). Berlin: Dietz, 1990, v. 40, p. 516. Sobre a diferença entre alienação e estranhamento, nos Manuscritos de 1844, cf. CHAGAS, Eduardo F. Diferença entre alienação e estranhamento nos Manuscritos Econômico-Filosóficos (1844), de Karl Marx. Revista Educação e Filosofia. Uberlândia: Universidade Federal de Uberlândia, v. 8, n. 16, p. 23-33, junho/dezembro de 1994.

${ }^{24}$ MARX, K. Ökonomisch-philosophische Manuskripte. op. cit., p. 517.

${ }^{25}$ Cf. MARX, K.: "Uma aranha executa operaçôes semelhantes às do tecelão, e uma abelha supera mais de um arquiteto ao construir sua colméia. Mas o que distingue o pior arquiteto da melhor abelha é que ele constrói em sua mente sua construção, antes de construí-la em realidade. [...], ele imprime igualmente ao material a sua finalidade, pois ele sabe que ela determina o modo e a maneira de seu fazer
} 
atividade muda dos animais, produz sua existência, cria a consciência de que é um ser social e, assim, atinge a existência de um ser universal e livre. Por isso, o sujeito só se constitui como ser universal e livre à medida que é sujeito de uma atividade livre e consciente. Contudo, o que fundamenta o ser genérico do sujeito é, precisamente, o trabalho, que, nas condiçóes da sociedade capitalista, se torna estranhado.

Marx evidencia quatro conexóes em que se apresenta o trabalho estranhado: 1. a do sujeito com seu produto, 2. do sujeito com sua atividade produtiva, 3. do sujeito com sua vida genérica; e, por fim, 4. do sujeito com outros sujeitos. Marx mostra que, na produção burguesa, o produto, resultado da objetivação do trabalho, deixa de ser, para o sujeito, seu próprio ser objetivado, para ser apenas um objeto estranho que o enfrenta e escraviza. $\mathrm{O}$ objeto produzido pelo sujeito - seu produto - opóe-se a ele como ser estranho, volta-se contra seu produtor e passa a dominá-lo. O sujeito exterioriza suas qualidades subjetivas no objeto, póe sua vida nele, porém, agora, esta náo lhe pertence, mas ao objeto. Em decorrência, quanto mais objetos o sujeito produzir, tanto menos pode deles se apropriar e mais se subjuga ao domínio de seu produto; "[...] quanto mais formado o seu produto, tanto mais deformado o trabalhador, quanto mais civilizado o seu objeto, tanto mais bárbaro o trabalhador." ${ }^{26}$ A essa objetivação estranhada corresponde uma subjetivação estranhada, pois a perda do objeto produzido, da produção dos meios necessários à própria produção, enfim, de tudo o que significa produção pelo trabalho humano, não é só material, porém, recai também no mundo interior, na subjetividade humana. Há, pois, uma inversão de valores: um empobrecimento da subjetividade, uma desvalorizaçâo do sujeito diante de uma valorização da coisa, de um enriquecimento do objeto, do produto do trabalho.

À medida que o produto é estranho ao sujeito, a própria atividade produtiva se lhe torna alheia; o próprio trabalho se converte em atividade externa, que lhe produz deformação e unilateralização. Por isso, o sujeito só pode sentir-se em si fora do trabalho, porque neste está fora de si; agora, sua realização evidencia-se nas funçôes puramente animais - comer, beber, procriar etc. Nessas condiçóes, o elemento humano torna-se animal e o animal, humano. Desse modo, quando o sujeito se confronta com o trabalho

como lei e a ela ele subordinar a sua vontade." (MARX, K. Das Kapital. In: MARX, K.; ENGELS, F. Werke (MEGA). Berlin: Dietz, 1962, v. 23, p. 193.

${ }^{26}$ MARX, K. Ökonomisch-philosophische Manuskripte. op. cit., p. 513. 
estranhado - como uma atividade não típica de sua espécie, não própria de seu gênero - o seu ser genérico (tanto no que diz respeito à sua natureza física como às suas faculdades espirituais específicas) converte-se num ser alheio a ele próprio. De fato, o trabalho, como atividade livre e consciente, o qual especifica a generalidade do sujeito e o distingue do animal, é-lhe negado e se transforma em simples atividade de subsistência e contraposta aos demais seres humanos. Nessa atividade específica, que é repetitiva, fatigante e negadora da essência humana, o sujeito, assegura Marx, "[...] não se afirma, portanto, em seu trabalho, mas nega-se a si mesmo; não se sente bem, mas infeliz, não desenvolve livremente nenhuma energia física e espiritual, mas mortifica sua physis [seu corpo] e arruína seu espírito." 27 Afastado de seu ser genérico, da vida de sua espécie, o sujeito, como mercadoria, como força de trabalho, restringese a uma existência corpórea, biológica, preso às condiçóes mais elementares e menos desenvolvidas de sua própria espécie, ou seja, àquelas condiçóes de sobrevivência imediata e de reprodução física.

O que se considera com relação ao estranhamento do sujeito ante o seu produto, a sua própria atividade e a sua vida genérica, evidencia-se também na relação dele com os outros sujeitos. Ressalta Marx: "[...] quando o homem está frente a si mesmo, defronta-se a ele o outro homem.." ${ }^{28}$ Trata-se aqui do estranhamento interno ao próprio sujeito, que implica um estranhamento intersubjetivo, isto é, numa relação estranhada do sujeito com outros sujeitos. $\mathrm{O}$ sujeito, reduzido à força de trabalho, à mercadoria, relacionando-se com outros sujeitos, vistos também como coisas, meramente como sujeitos físicos - é isto o princípio que conduz as relaçóes intersubjetivas, inter-humanas, nas quais se expressa o estranhamento dos próprios sujeitos. No entanto, se "[...] o produto do trabalho me é estranho e enfrenta-me como um poder estranho, a quem pertence ele então? Se minha própria atividade não me pertence, mas é uma atividade estranhada, forçada, a quem ela pertence então? A um outro ser que não eu. E quem é esse ser? Os deuses?" ${ }^{29}$. Este outro ser a quem pertence o produto do trabalho é, na verdade, também um sujeito, um outro sujeito que não o trabalhador, ou seja, o capitalista. Esse momento revela-se, por um lado, pelo fato de que certo número de sujeitos produz para outros e, por isso, náo tem o controle sobre o produto de seu próprio trabalho; por outro, pelo fato de um número reduzido de sujeitos - os capitalistas - que

\footnotetext{
${ }^{27}$ MARX, K. Ökonomisch-philosophische Manuskripte. op. cit., p. 514.

${ }^{28}$ Ibid., p. $517-518$.

${ }^{29}$ Ibid., p. 518.
} 
não trabalha, apropria-se do produto alheio. Desse modo, podemos sustentar que tanto os trabalhadores quanto os capitalistas são estranhos um em face do outro; contudo, as consequências são diversas: o estranhamento para o sujeito trabalhador evidencia-se como miséria, sofrimento e desumanização, enquanto, para o sujeito capitalista, como riqueza, deleite e satisfação.

Se o trabalho estranhado afasta do sujeito o produto de seu trabalho, a reconciliação do sujeito com o objeto de sua atividade dá-se, nessas condiçóes, através da posse, do dinheiro. E o sujeito mesmo expressa seu ser não em si, mas fora de si, no ter, na posse do dinheiro. Também os seus afetos, carinho, desejo, amor, para com os demais sujeitos se afirmam apenas no dinheiro. Como declara Marx:

[...] o que o dinheiro pode comprar, isso sou eu, o possuidor do próprio dinheiro. Tão grande quanto a força do dinheiro é a minha força. As qualidades do dinheiro são as minhas - de seu possuidor - qualidades e forças essenciais. Aquilo que eu sou e posso não é, portanto, de modo algum determinado por minha individualidade. Eu sou feio, mas posso comprar para mim a mulher mais bela. Portanto, eu náo sou feio, pois o efeito da feiúra, sua força repelente, é anulado pelo dinheiro. Eu - segundo minha individualidade - sou coxo, mas o dinheiro me proporciona vinte $\mathrm{e}$ quatro pés; eu não sou, portanto, coxo; eu sou um ser humano mau, sem honra, sem escrúpulos, sem espírito, mas o dinheiro é honrado e, portanto, também o seu possuidor. ${ }^{30}$

Já a ausência de dinheiro tem o significado humano de o ser não ser sem o ter, ou seja, de o ser não ter em si qualquer objetivo, pois, “[...] se não tenho dinheiro para viajar, não tenho necessidade alguma, isto é, nenhuma necessidade efetiva e que se realize para viajar. $\mathrm{Eu}$, se tenho vocaçáo para estudar, mas não tenho dinheiro algum para isto, não tenho nenhuma vocação para estudar, isto é, nenhuma vocação efetiva, verdadeira" 31 Nessas condiçôes, em que o mundo humano é apropriado pelo dinheiro, pela posse, o sujeito torna-se estranho à sua própria sensibilidade. Por conseguinte, quando ele vê um objeto e almeja tê-lo em sua vida, fica sensível apenas na possibilidade de tê-lo para si como capital, de utilizá-lo ou possuí-lo diretamente. Por exemplo: "O comerciante de minerais vê apenas o valor mercantil, mas não a beleza e natureza peculiar do mineral; ele não tem sentido mineralógico algum". ${ }^{32}$

\footnotetext{
${ }^{30}$ MARX, K. Ökonomisch-philosophische Manuskripte. op. cit., p. 564.

${ }^{31}$ Ibid., p. 566.

${ }^{32}$ Ibid., p. 542.
} 
Assim, para Marx, o capitalismo, a fim de aumentar a produção de capital, de satisfazer a sua objetividade por acúmulo de riqueza, reduz o ser ao ter, as necessidades humanas à necessidade de possuir dinheiro, empobrecendo, dessa forma, o sujeito em suas faculdades intelectuais, subjetivas.

A relaçáo de propriedade privada, isto é, do sujeito com ela, implica uma apropriação limitada da vida. Os objetos somente são tidos como do sujeito na condição exclusiva de pertencimento como propriedade. Os sentidos do sujeito, físicos e intelectuais, deixam de expandir, quando restritos às delimitaçóes impostas pela posse. Por isso, salienta Marx:

A suprassunção da propriedade privada é, pois, a emancipação completa de todas as qualidades e sentidos humanos; mas ela é esta emancipaçáo precisamente porque esses sentidos e qualidades tornaram-se humanos, tanto subjetiva quanto objetivamente. $\mathrm{O}$ olho tornou-se olho humano quando seu objeto se tornou um objeto humano, social, proveniente do homem para o homem. ${ }^{33}$

Portanto, os sentidos tornam-se humanos, quando os sentidos do sujeito encontram nos seus objetos uma satisfação liberta da propriedade privada e passam a refletir o trabalho como uma atividade cooperativa, de mútuo intercâmbio, a qual não condiciona o sujeito trabalhador ao estranhamento do produto do trabalho. Nesse caso, os objetos do trabalho deixam de ser cobiçados como propriedade para adquirirem uma nova forma, em que se confirmam as forças essenciais, as capacidades subjetivas do sujeito, a fim de lhe satisfazerem plenamente.

A temática da subjetividade humana pode ser apreendida também nos Grundrisse e em $O$ Capital. Na primeira obra, Marx parte da produção material, socialmente determinada, e demonstra que ela é um todo orgânico, dinâmico, uma rica totalidade de relaçóes diversas, na qual seus momentos constitutivos, a distribuição, a troca e o consumo estão concatenados entre si, formando unidade sintética, embora contraditória: a produçáo oferece, na forma material, o seu objeto, ou seja, os elementos materiais do consumo, pois sem objeto não há consumo. A produção determina, porém, não só a forma objetiva, como também subjetiva do objeto, quer dizer, ela não só fornece o objeto material à necessidade do consumidor, como também "cria subjetivamente" o consumidor, a sua necessidade, ao determinar o modo, a

${ }^{33}$ MARX, K. Ökonomisch-philosophische Manuskripte. op. cit., p. 540. 
forma específica em que o objeto deve ser consumido. Como frisa Marx: "A fome é a fome, mas a fome que se satisfaz com carne cozida, comida com faca e garfo, não é a mesma fome que devora a carne crua com ajuda da mão, da unha, do dente." ${ }^{4}$ Da mesma maneira: "O objeto de arte - tal como qualquer outro produto - cria um público sensível à arte e capaz de desfrutar a beleza." 35 Portanto, a produção cria não só um objeto para o sujeito (para o consumo), mas também um sujeito para o objeto, ao determinar o modo de consumir o objeto e a necessidade no sujeito desse objeto (o apetite, o desejo do consumo). E o consumo é o móbil que impulsiona a produção, que póe em movimento o processo produtivo, à medida que ele produz a necessidade de um novo objeto, de uma nova produção. Entre a produção e o consumo situa-se a distribuição, que não pode ser uma repartição coletiva, igualitária, dos produtos, porque ela não é independente, e sim determinada inteiramente pela estrutura da produção, que é privada, particular. Nesse sentido, a distribuiçáo dos produtos é determinada pela forma da produção (privada), da distribuição dos instrumentos de produção (privados) e da função (capital e trabalho) dos membros da sociedade na produção. Analogamente, a troca não é independente e indiferente à produção, e, se a produção é privada, a troca também o é. Em decorrência, produção, distribuição, troca e consumo são elos de um todo único; eles não são idênticos nem exteriores um ao outro, mas momentos diferentes, embora recíprocos, no interior de uma unidade, de uma totalidade orgânico-dialética.

$\mathrm{Na}$ obra indicada, os Grundrisse, Marx destaca que o que especifica a sociedade capitalista é o valor de troca, o capital, e este determina o nexo da sociedade, o convívio social entre os sujeitos, fazendo com que estes assumam a forma de coisa. Escreve ele: "A dependência mútua e generalizada dos indivíduos reciprocamente indiferentes forma a sua conexão social. Esta conexão social está expressa no valor de troca [...], isto é, num universal, no qual toda individualidade, toda particularidade, é negada e cancelada." ${ }^{36}$ E mais:

O caráter social da atividade, tal como a forma social do produto e a participação do indivíduo na produçáo, aparece aqui como algo estranho e com caráter de coisa frente aos indivíduos; não como seu estar reciprocamente relacionados, mas como seu estar subordinados a relaçôes que subsistem independentemente deles e nascem do choque dos

\footnotetext{
${ }^{34}$ MARX, K. Grundrissen der Krtik der polistischen Ökonomie. In: MARX, K.; ENGELS, F. Werke (MEGA). Berlin: Dietz, 1983, v. 42, p. 27.

35 Ibid., p. 27.

${ }^{36}$ Ibid.., p 90-91.
} 
indivíduos reciprocamente indiferentes. $\mathrm{O}$ intercâmbio geral das atividades e dos produtos, que se converte em condição de vida para cada indivíduo particular e é sua conexão recíproca com os outros, aparece a eles próprios como algo estranho, independente, como uma coisa. No valor de troca, o vínculo social entre as pessoas transforma-se em relação social entre coisas; a capacidade pessoal, em uma capacidade das coisas. ${ }^{37}$

Marx destaca aqui a indiferença, o alheamento, como a característica particular do sujeito na sociedade capitalista. É o capital, o valor de troca, o dinheiro, que medeia as relaçóes sociais, eliminando as diferenças sociais dos sujeitos ou tornando-as indiferentes. Essa indiferença entre os sujeitos, na sociedade capitalista, é uma consequência do modo de produção capitalista, o qual elimina não só as determinaçóes particulares em relação aos sujeitos e as diferenças qualitativas dos produtos, das propriedades, dos atributos particulares das coisas (cor, cheiro, peso etc.), isto é, daquilo que distingue materialmente os valores de uso particulares das coisas, tornando-as meras mercadorias, como também as formas específicas do trabalho útil-concreto, reduzindo-os, por conseguinte, a uma única espécie de trabalho, a trabalho humano abstrato. ${ }^{38}$ Logo, nas condiçóes do capitalismo, o sujeito se determina como força de trabalho, como mercadoria, como coisa. E, como coisa, as relaçóes entre os sujeitos se transformam em relaçóes entre coisas; cada um é indiferente ao outro, está separado dos demais, levando o sujeito a um completo isolamento social, a uma ausência de sociabilidade.

Um texto importante sobre a subjetividade reificada é, precisamente, "O Caráter Fetichista da Mercadoria e o seu Segredo", publicado em $O$ Capital. Investigando o fetichismo da mercadoria, Marx observa que o caráter "místico", "enigmático", da mercadoria não provém de seu valor de uso, mas da forma do valor, do valor de troca. Assim ele descreve o fenômeno do fetichismo da mercadoria:

O mistério da forma mercadoria consiste, portanto, simplesmente no fato de que ela reflete aos homens as características sociais de seu próprio trabalho como características objetivas dos produtos do trabalho mesmo, como qualidades naturais sociais destas coisas, por isso, também reflete a relação social dos produtores com o trabalho total como uma relação social

\footnotetext{
${ }^{37}$ MARX, K. Grundrissen der Krtik der polistischen Ökonomie. Op. cit., p 91.

${ }^{38}$ Sobre a distinção entre trabalho útil-concreto e trabalho abstrato em Marx, cf. CHAGAS, Eduardo F. A natureza dúplice do trabalho em Marx: Trabalho útil-concreto e trabalho abstrato. Revista Outubro, no. 19, p. 61-80, 2011.
} 
de objetos, que existe fora deles. Por meio desses quiproquós os produtos do trabalho se tornam mercadorias, coisas sociais, sensíveis e suprasensíveis. [...] É apenas a relaçáo social determinada dos próprios homens, tomada aqui por eles como a forma fantasmagórica de uma relaçáo entre coisas. $[\ldots]$

Já que os produtores somente entram em contato social mediante a troca dos produtos de seu trabalho, também as características especificamente sociais de seus trabalhos privados só aparecem dentro dessa troca. [...] Por isso, aos últimos [aos produtores], as relaçóes sociais entre seus trabalhos privados aparecem como o que elas são, isto é, não como relaçóes imediatamente sociais entre pessoas em seus próprios trabalhos, mas, pelo contrário, como relaçôes reificadas entre as pessoas e relações sociais entre as coisas. ${ }^{39}$

Marx enfatiza, aqui, a condição trágica da subjetividade no mundo, pois, no processo produtivo de mercadorias, cria-se uma objetividade que anula os próprios sujeitos. Marx destaca a presença de uma objetividade sem subjetividade, ou de uma subjetividade mutilada, esvaziada, para qual a realidade aparece como um mundo exterior; quer dizer, o sujeito desconhece o mundo, a sua própria atividade, as condiçóes pelas quais se produzem a sua própria existência, percebendo o mundo, a existência real, como fora dele, externa e alheia a ele, e não como um produto de seu próprio trabalho, de sua própria subjetividade. Marx vê aqui o anúncio da "morte" do sujeito, já que, nessas condiçóes fetichizadas, os sujeitos enquanto sujeitos ativos, livres e conscientes são abolidos e se tornam coisas vivas (de ordem mercadológica), e os produtos de seu trabalho, as mercadorias, aparecem como atributos de si mesmas, autonomizadas, dotadas de um poder sobrenatural, ocultando, dessa maneira, a sua origem, a sua fonte, isto é, o trabalho social que as fundamenta.

${ }^{39}$ MARX, K. Das Kapital. op. cit., p. 86-87. 
CHAGAS, Eduardo F. Marx's thinking on subjectivity. Trans/Form/Ação, Marília, v. 36, n. 2, p. 63-84, Maio/Ago., 2013.

\begin{abstract}
Marx's thinking about human subjectivity is little discussed in the Portuguese language, and in Brazil in particular it still lacks an ample, explicit and systematic study. The article aims at delineating a more complete reflection on his thinking on human subjectivity, emphasizing not only criticism, but also, and in a special manner, an understanding of the issue starting from an immanent and structurally-based reading of his works in the original. It is also worth noting that this investigation is based on the connection between subjectivity and objectivity, between subject and object, inquiring whether these two concepts contradict themselves within Marx's thought, compromising in this fashion his critical reflections on Hegel's speculative philosophy and the empiricism of classical economy, or whether in fact a connection between the two is a deeply buried secret of Marx's philosophy on human subjectivity.
\end{abstract}

KEYWORDS: Marx, Subjectivity, Determinism.

\title{
REFERÊNCIAS
}

ARAÚJO, Ronaldo Marcos de Lima; TEODORO, Elinilze Guedes. Aproximaçóes para entender a subjetividade numa perspectiva marxista. Revista Trabalho e Educação: NETE/ UFMG. Vol. 15, nº 01, 2006.

BERINO, Aristóteles P. Elementos para uma teoria da subjetividade em Marx. Dissertação (Mestrado) - Niterói/RJ, 1994 (mimeo).

BERTRAND, Michele. O homem clivado - A crença e o imaginário. In: Elementos para uma teoria marxista da subjetividad. São Paulo: Vértice, 1989.

CHAGAS, Eduardo F. A crítica da política em Marx. In: Trabalho, Filosofia e Educação no Espectro da Modernidade Tardia. Fortaleza: Ediçōes UFC, 2007.

CHAGAS, Eduardo F. Diferença entre alienação e estranhamento nos Manuscritos Econômico-Filosóficos (1844), de Karl Marx. Revista Educą̧ão e Filosofia. Uberlândia: Universidade Federal de Uberlândia, v. 8, n. ${ }^{\circ}$ 16, p. 23-33, junho/dezembro de 1994.

CHAGAS, Eduardo F. O Método Dialético de Marx: investigação e exposição crítica do objeto. Sintese - Revista de Filosofia. Belo Horizonte, v. 38, no 120, p. 55-70, 2011.

CHAGAS, Eduardo F. A natureza dúplice do trabalho em Marx: Trabalho útil-concreto e trabalho abstrato. Revista Outubro, no. 19, p. 61-80, 2011.

CHAGAS, Eduardo F. Religiáo: O homem como imagem de Deus ou Deus como imagem do homem. In: Formação Humana: Liberdade e Historicidade. Fortaleza: Ediçóes UFC, 2004. 
MARTINS, Maurício Vieira. Materialismo e Subjetividade: estudando a posição de Marx. In: MORAES, João Quartim de (Org.). Materialismo e Evolucionismo - Epistemologia e História dos Conceitos. Campinas: FAPESP, 2007, p. 103-130. (Coleção CLE, vol. 47).

MARX, K. Vorwort zur Kritik der politischen Ökonomie. In: MARX, K.;ENGELS, F. Werke (MEGA). Berlin: Dietz, 1983, v. 13.

MARX, K. Theorien über den Mehrwert. In: MARX, K.; ENGELS, F. Werke (MEGA). Berlin: Dietz, 1965, v. 26.

MARX, K. Zur Judenfrage. In: MARX, K.; ENGEL, F. Werke (MEGA). Berlin: Dietz, 1957, v. 1 .

MARX, K. Ökonomisch-philosophische Manuskripte. In: MARX, K.; ENGELS, F. Werke (MEGA). Berlin: Dietz, 1990, v. 40.

MARX, K. Der achtzehnte Brumaire des Louis Bonaparte. In: MARX, K.; ENGELS, F. Werke (MEGA). Berlin: Dietz, 1960, v. 8.

MARX, K. Zur Kritik der hegelschen Rechtsphilosophie. Einleitung. In: MARX, K.; ENGELS, F. Werke (MEGA). Berlin: Dietz, 1957, v. 1.

MARX, K. Die deutsche Ideologie. In: MARX, K.; ENGELS, F. Werke (MEGA). Berlin: Dietz, 1958, v. 3.

MARX, K. Thesen über Feuerbach. In: MARX, K.; ENGELS, F. Werke (MEGA). Berlin: Dietz, 1958, v. 3.

MARX, K. Grundrissen der Krtik der polistischen Ökonomie. In: MARX, K.; ENGELS, F. Werke (MEGA). Berlin: Dietz, 1983, v. 42.

MARX, K. Das Kapital. In: MARX, K.; ENGELS, F. Werke (MEGA). Berlin: Dietz, 1962, v. 23 .

SILVEIRA, Maria Lídia Souza da. Algumas notas sobre a temática da subjetividade no âmbito do marxismo. Revista Outubro, No. 7, 2002.

SILVEIRA, Paulo; DORAY, Bernard. Elementos para uma teoria marxista da subjetividade. São Paulo: Vértice, 1989.

Recebido em: 02.01.2012

Aceito em: 03.12.2012 